\title{
STRATEGI MULTI REPRESENTASI DENGAN KEMAMPUAN PEMECAHAN MASALAH MATEMATIS SISWA
}

\author{
Kartini Hutagaol \\ FKIP Universitas Advent Indonesia \\ Email: kartinih_smant@yahoo.com
}

\begin{abstract}
Abstrak
Penelitian ini bertujuan untuk: (1) membangun kepercayaan, kebebasan dalam diri siswa melalui bentuk representasi yang dipilihnya, (2) mengetahui peningkatan (gain) kemampuan pemecahan masalah matematis siswa, dan (3) mengetahui interaksi antara faktor pembelajaran dengan gain kemampuan pemecahan masalah matematis siswa. Penelitian ini adalah penelitian eksperimen dengan desain kelompok kontrol, pretes dan postes. Populasi penelitian ini adalah siswa SMP Kabupaten Bandung Barat. Sedangkan sampelnya adalah diambil dua kelas secara acak siswa kelas VIII SMP Negeri 1 Cisarua mewakili sekolah level sedang dan dua kelas siswa kelas VIII SMP Negeri Satu Atap Kertawangi mewakili siswa sekolah level rendah. Hasil temuan dalam penelitian ini adalah bahwa peningkatan atau gain siswa yang belajar dengan strategi multi representasi berbeda secara signifikan dibandingkan dengan gain kemampuan pemecahan masalah matematis siswa yang belajar dengan konvensional. Siswa yang berpengetahuan awal tinggi lebih memilih representasi aljabar dan lebih terampil dalam menggunakan berbagai bentuk reprentasi, siswa yang berpengetahuan awal sedang lebih memilih representasi tabel dan siswa yang berpengetahuan awal rendah lebih menyukai representasi skema. Selanjutnya interaksi yang terjadi lebih efektif pada siswa yang berpengetahuan awal sedang dan rendah.
\end{abstract}

Kata Kunci: Strategi Multi Representasi, Kemampuan Pemecahan Masalah Matematis siswa.

\begin{abstract}
This study aims to: (1) build trust, freedom in students through their chosen form of representation, (2) to know the improvement of students' mathematical problem solving ability, and (3) to know the interaction between learning factor and gain mathematical problem solving ability students. This research is an experimental research with control group design, pretest and postes. The population of this research is junior high school student of West Bandung Regency. While the sample is taken two classes at random class VIII students SMP Negeri 1 Cisarua representing middle school and two classes of students of class VIII SMP Negeri Satu Atap Kertawangi representing low school level students. The findings in this study are that the increase or gain of students who learn with multirepresentation strategy is significantly different compared with the gain of mathematical problem solving ability of students who study with conventional. Students with a high prior knowledge prefer algebraic representation and are more skilled in using various forms of reprentation, early knowledgeable students prefer desk representation and low-priority students prefer schematic representations. Furthermore, the interaction is more effective for students with moderate and low knowledge.
\end{abstract}

Keywords: Multi Representation Strategy, Student Mathematical Problem Solving Ability. 


\section{Pendahuluan}

Kemampuan pemecahan masalah matematis sangat diperlukan dalam belajar matematika, bahkan perlu bagi siswa dalam menghadapi masalah-masalah dalam kehidupannya. Kemampuan pemecahan masalah adalah komponen penting dalam belajar matematika dan merupakan tujuan pengajaran matematika, bahkan pemecahan masalah merupakan jantungnya matematika (Ruseffendi,1991).

Dengan kemampuan pemecahan masalah, siswa akan mempunyai kemampuan dasar yang bermakna lebih dari sekedar kemampuan berpikir, dan dapat membuat strategi-strategi penyelesaian untuk masalah-masalah selanjutnya. Pemecahan masalah dapat mempertajam kekuatan analisis dan kekuatan kritis siswa. Namun demikian pemecahan masalah masih dianggap sebagai bagian yang paling sulit dalam matematika, baik oleh siswa yang mempelajarinya maupun guru dalam mengajarkannya, Suryadi dkk (Suherman, 2001).

Hutagaol (2007) mengemukakan bahwa sebagian besar siswa takut dalam memberikan pertimbangan atas solusi pemecahan masalah matematika yang dihadapkan kepadanya, siswa kurang percaya diri dalam menjawab pertanyaan: mengapa, dan bagaimana. Hal ini menunjukkan bahwa guru melakukan pengajaran matematika di sekolah cenderung mengutamakan kepada hapalan, menggunakan cara yang paling mudah dan praktis, yang seharusnya guru memilih cara bagaimana membuat siswa belajar dengan pengertian sehingga dapat memahami pertanyaan matematika yang dihadapkan terhadap siswa tersebut. Siswa sebaiknya diarahkan dengan pembelajaran bermakna mengutamakan kepada pengertian, proses, yang mampu mengaitkan pengetahuan baru melalui pengetahuan lama. Sehingga memahami materi bukan sekedar tahu, tetapi mampu menjadi diri sendiri.

Salah satu strategi yang berorientasi pada proses dan pengertian yang diharapkan untuk meningkatkan kemampuan pemecahan masalah matematis siswa adalah strategi multi representasi. Dengan strategi multi representasi siswa dapat membangun kepercayaan dirinya melalui bentuk representasi yang dipilihnya. Siswa tidak kehilangan rasa percaya diri, tidak merasa takut, dan rendah diri. Siswa merasa dihargai dan dimengerti, karena guru menghargai pendapat anak, sekalipun sederhana (informal) tetapi dapat dituntun untuk meningkat ke formal. Siswa memperoleh kebebasan untuk memilih bentuk representasi yang mereka inginkan serta yang cocok (benda kongkrit, gambar, model, skema, grafik, tabel dan bentuk aljabar) untuk menyajikan atau menyelesaikan masalah yang mereka hadapi. Solusi yang beragam yang dimunculkan oleh siswa dimanipulasi secara cerdik oleh guru melalui interaksi serta refleksi menuju pengetahuan formal yang ingin dipelajari (Sabandar 2006). 
Penggunaan bentuk-bentuk representasi yang berbeda sangat berpengaruh dalam mengklarifikasi solusi pemecahan suatu masalah. Kramarski (2000) ${ }^{1}$, mengemukakan bahwa dalam menyampaikan ide-ide matematika perlu menggunakan bentuk-bentuk representasi yang berbeda, untuk pencapaian kemampuan pada tingkat tertentu dalam membaca, menulis, menjelaskan, mendiskusikan, dan mengklarifikasi ide-ide matematika. Sedangkan Kalathil \& Serrín $(2000)^{1}$, meneliti tentang peran representasi siswa dalam pembelajaran matematika, yang menekankan bahwa peran representasi eksternal yang dapat digunakan untuk membantu perkembangan pemahaman siswa dan didasarkan pada pandangan konstruktivis.

Selanjutnya penelitian ini bertujuan untuk: (1) membangun kepercayaan, kebebasan dalam diri siswa melalui bentuk representasi yang dipilihnya, (2) mengetahui peningkatan (gain) kemampuan pemecahan masalah matematis siswa, dan (3) mengetahui interaksi antara faktor pembelajaran dengan gain kemampuan pemecahan masalah matematis siswa. Pertanyaan yang diajukan pada bagian rumusan masalah adalah: 1) Bagaimana pemilihan bentuk representasi siswa berdasarkan faktor pengetahuan awal baik pada sekolah level sedang dan rendah? 2) Apakah terdapat perbedaan yang signifikan pada gain kemampuan pemecahan masalah matematis antara siswa yang menggunakan strategi multi representasi dan konvensional pada sekolah level menengah? 3) Apakah terdapat perbedaan yang signifikan pada gain kemampuan pemecahan masalah antara siswa yang menggunakan strategi multi representasi dan konvensional pada sekolah level rendah? 4) Apakah terjadi interaksi antara faktor pembelajaran dengan gain kemampuan pemecahan masalah matematis siswa berdasarkan pengetahuan awal dan level sekolah?

\section{Metode Penelitian}

Desain yang digunakan dalam penelitian ini adalah desain pretes dan postes yang digabung dengan desain $3 \times 2 \times 2$, yaitu tiga kelompok pengetahuan awal siswa (tinggi, sedang, rendah), dua level sekolah (sekolah level sedang, dan sekolah level rendah), dan dua strategi pembelajaran (strategi multi representasi, dan strategi biasa). Desain yang digunakan dalam penelitian ini dapat dinyatakan sebagai berikut:

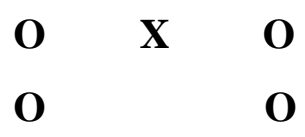

1 "Kalathil.pdf." 
Keterangan

O: Pretes dan Postes

$\mathrm{X}$ : Perlakuan pembelajaran dengan menggunakan strategi multi representasi

Pada kelas eksperimen diberi perlakuan pembelajaran dengan strategi multi representasi dan pada kelas kelompok kontrol diberi perlakuan dengan strategi biasa. Pada kedua kelompok diberi pretes dan postes.

Populasi dalam penelitian ini adalah seluruh siswa SMP di Kabupaten Bandung Barat. Sampel penelitian ini adalah siswa kelas dua SMP Negeri Satu Cisarua mewakili sekolah level sedang, dan siswa kelas dua SMP Negeri Satu Atap Kertawangi mewakili sekolah level rendah. Pengujian hipotesis pada penelitian ini menggunakan uji-t, ANOVA satu jalur, dan ANOVA dua jalur yang diteruskan uji lanjut dengan bantuan perangkat lunak SPSS-16 for windows.

\section{Hasil Penelitian}

Dalam menemukan solusi pemecahan masalah perkalian dalam bentuk aljabar, siswa dihadapkan dengan bentuk representasi yang hendak dipilihnya. Hasilnya tampak bahwa siswa berpengetahuan awal tinggi cenderung memilih bentuk representasi aljabar, siswa berpengetahuan awal sedang memilih bentuk representasi tabel dan siswa berpengetahuan awal rendah lebih memilih bentuk representasi skema.

Persentase rerata gain kemampuan pemecahan masalah matematis siswa yang berpengetahuan awal tinggi yang menggunakan strategi multi representasi, dan konvensional tidak jauh berbeda, hal itu terjadi pada sekolah level sedang dan sekolah level rendah. Namun demikian pada siswa berpengetahuan awal sedang dan rendah pada kedua level sekolah adalah berbeda (Gambar 1). Selanjutnya dilihat dari besarnya deviasi gain, bahwa deviasi gain pada siswa yang belajar dengan strategi konvensional lebih besar daripada deviasi gain yang menggunakan strategi multi representasi (Gambar 1). Secara keseluruhan Gain kemampuan pemecahan masalah matematis siswa yang memperoleh strategi multi representasi berbeda secara siginifikan daripada siswa yang memperoleh strategi biasa. 


\section{Gambar 1. Rerata ( $\bar{X}$ ) dan deviasi ( $S$ ) Gain (\%) Pemecahan Masalah Matematis}

Sekolah Level Sedang dan Rendah

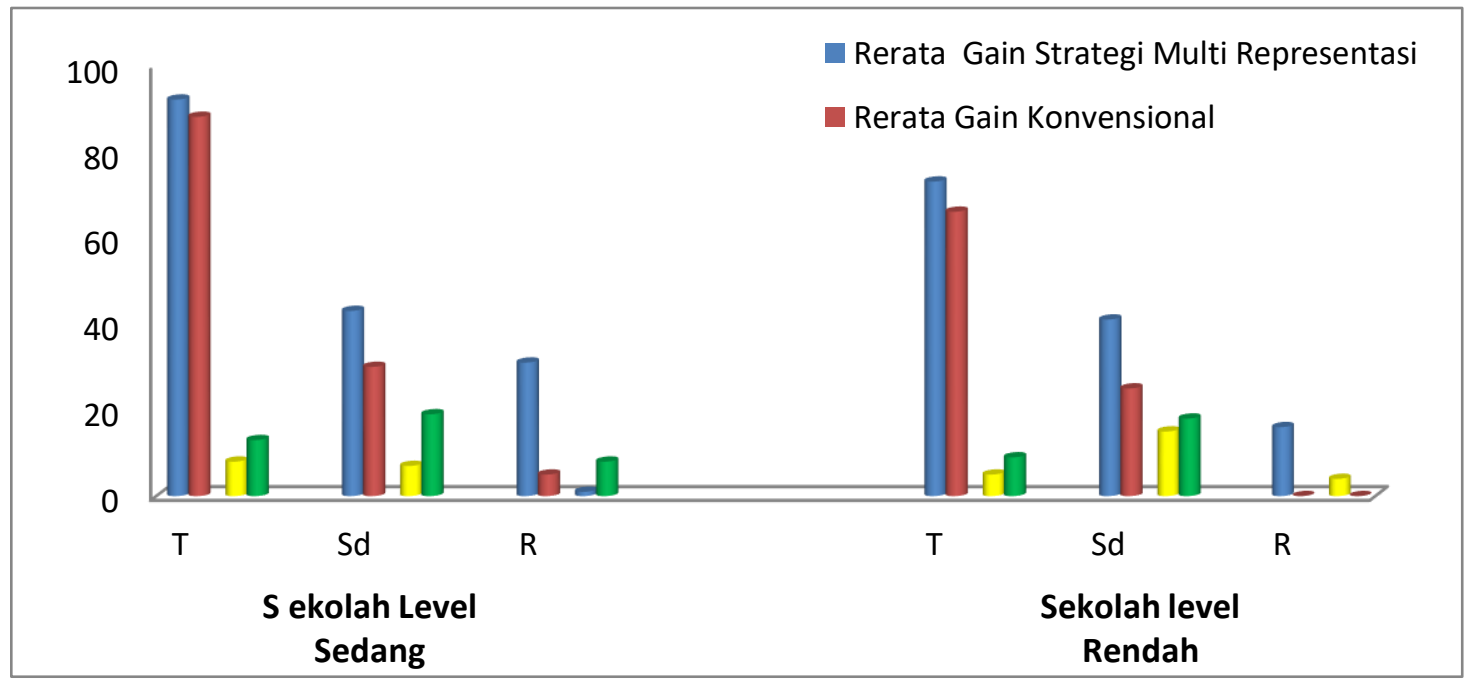

\section{Keterangan:}

$\square$ Deviasi Gain Strategi Multi Representasi

$\square$ Deviasi Gain Strategi Konvensional

$\mathrm{T}$ : Siswa berpengetahuan awal tinggi

$\mathrm{Sd}$ : Siswa berpengetahuan awal sedang

$\mathrm{R}$ : Siswa berpengetahuan awal rendah

Hasil pengujian hipotesis menunjukkan bahwa terdapat perbedaan yang signifikan pada peningkatan kemampuan pemecahan masalah matematis siswa yang menggunakan strategi multi representasi dibandingkan dengan peningkatan kemampuan pemecahan masalah matematis siswa yang menggunakan strategi konvensional pada sekolah level sedang. Hal yang sama terjadi pada sekolah level rendah bahwa terdapat perbedaan yang signifikan pada peningkatan kemampuan pemecahan masalah matematis siswa yang menggunakan strategi multi representasi dibandingkan dengan peningkatan kemampuan pemecahan masalah matematis siswa yang menggunakan strategi konvensional.

Pada siswa yang berpengetahuan awal tinggi tidak terjadi interaksi terhadap faktor pembelajaran, namun demikian terjadi interaksi pada siswa yang berpengetahuan awal sedang dan rendah di sekolah level sedang (Gambar 2). Selanjutnya terjadi juga pada sekolah level rendah, siswa yang berpengetahuan awal tinggi tidak ada interaksi terhadap faktor pembelajaran, tetapi terjadi interaksi pada siswa berpengetahuan awal sedang dan rendah (Gambar 3). 


\section{Gambar 2. Interaksi antara Faktor Pengetahuan Awal dengan \\ Faktor Pembelajaran Sekolah Level Sedang}

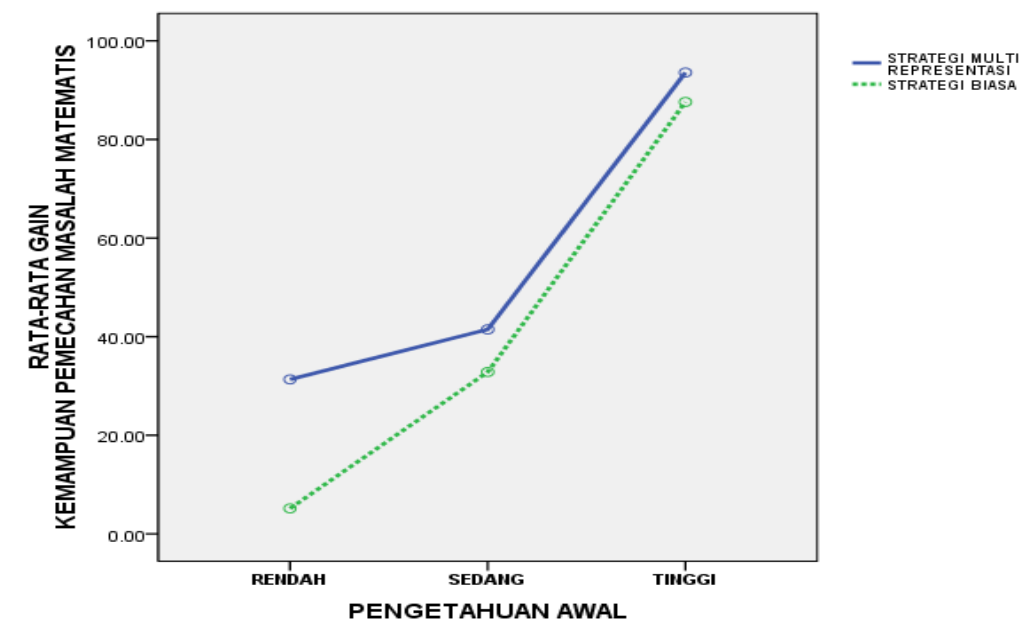

\section{Gambar 3. Interaksi antara Pengetahuan Awal Siswa dengan Faktor Pembelajaran pada Sekolah Level rendah}

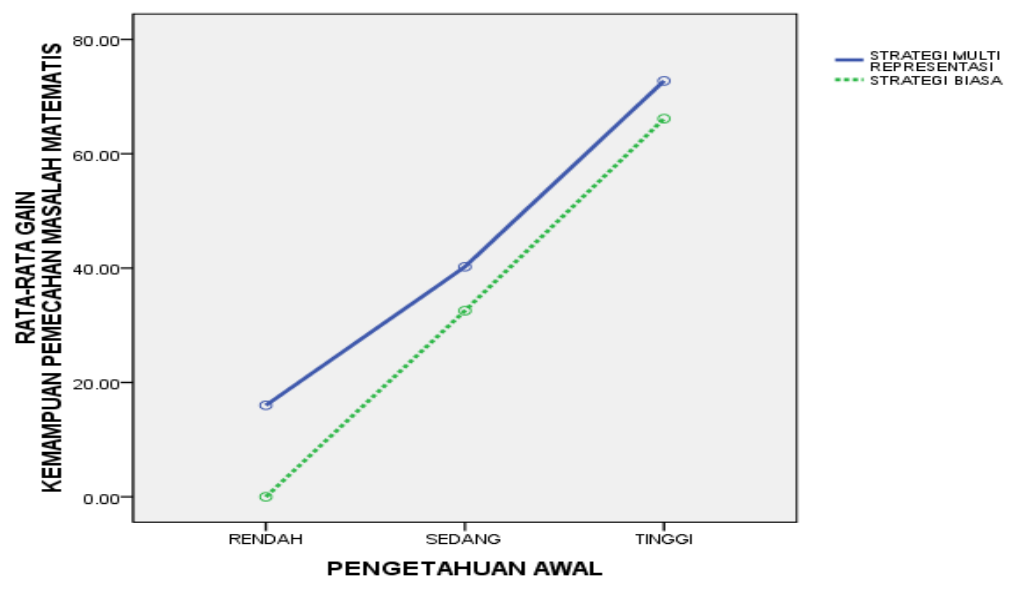

\section{Pembahasan}

Melalui ragam representasi atau pemilihan representasi, kemampuan siswa dalam menyampaikan ide-ide pemikirannya dapat teramati. Pemilihan representasi yang digunakan oleh siswa dalam menyelesaikan permasalahan-permasalahan yang diberikan, cukup berperan dalam mengamati solusi pemecahan masalah matematikanya. 
Siswa yang berkemampuan awal tinggi dalam menyelesaikan soal matematika yang benar, cenderung memilih bentuk representasi aljabar, dan lebih terampil dalam menggunakan berbagai bentuk representasi. Hasil ini didukung oleh Hutagaol (2008) dalam uji coba pendahulu, bahwa dari total 161 jawaban yang benar, hanya 3\% siswa yang menjawab benar dengan cara aljabar yaitu siswa yang berpengetahuan awal tinggi. Selebihnya 97\% siswa berkemampuan awal sedang dan rendah yang menjawab benar dengan cara verbal dan numerik, (Sumber Soal: UN SMP 2007/2008 Kab. Bandung Barat, Paket B no.7).

Neria dan Amit $(2005)^{2}$ menyatakan bahwa siswa yang memilih representasi dengan cara aljabar adalah siswa berkemampuan tinggi, dengan rata-rata skor tes 95\% - 97\%. Siswa yang memilih representasi numerik mempunyai rata-rata skor $76 \%-85 \%$, dan siswa yang memilih representasi verbal mempunyai rata-rata skor 68\%-75\%, (Neria \& Amit, $2005^{3}$ ).

Selanjutnya bahwa siswa yang berpengetahuan awal sedang lebih memilih bentuk representasi tabel dan siswa berpengetahuan awal rendah lebih memilih bentuk representasi skema. Sedangkan menurut Kieran $(2006)^{4}$ bahwa siswa berkemampuan tinggi lebih menyukai representasi grafik, sementara siswa berkemampuan rendah lebih memilih representasi tabel.

Baik di sekolah level sedang dan rendah tampak bahwa faktor pembelajaran berpengaruh secara signifikan terhadap peningkatan kemampuan pemecahan masalah matematis siswa, artinya bahwa peningkatan kemampuan pemecahan masalah matematis siswa yang menggunakan strategi multi representasi berbeda seca signifikan dibandingkan dengan peningkatan pemecahan masalah matematis siswa yang menggunakan strategi biasa. Hal ini terlihat pada penolakan daerah $\mathrm{H}_{0}$, dengan nilai probabilitas (sig.) $=0,032$ lebih kecil dari 0,05 pada sekolah level sedang. Pada sekolah level rendah nilai probabilitas (sig.) = 0,044 lebih kecil dari 0,05. Temuan ini juga dikuatkan oleh peneliti terdahulu yang menyatakan bahwa pembelajaran dengan Klasikal Multi Representasi (KMR) lebih efektif terhadap hasil belajar kemampuan matematik dan daya representasi siswa daripada pembelajaran Konvensional (Hudiono, 2005).

Faktor pembelajaran berpengaruh secara signifikan terhadap peningkatan kemampuan pemecahan masalah matematis siswa berpengetahuan awal sedang, dengan nilai probabilitas

\footnotetext{
2 "Neria, D. and Amit, M (2004). Students Preference of Non Algebraic Representations in Mathematical Comunication. Proceding of the International Group for the Psychology of Mathematics Education, Vol. 3 Pp 409-416."

${ }^{3}$ Ibid.

4 “457-Handbook-of-Research-on-the-Psychology-of-Mathematics-Educationa.pdf."
} 
$($ sig. $)=0,045$ pada sekolah level sedang, dengan nilai probabilitas pengetahuan awal sedang $($ sig. $)=0,049$ pada sekolah level rendah.

Kemudian pengaruh faktor pembelajaran lebih efektif pada siswa yang berpengetahuan awal rendah, dengan nilai probabilitas $($ sig. $)=0,000$ lebih kecil dari 0,05 pada sekolah level sedang, dan nilai probabilitas pengetahuan awal rendah (sig.) $=0,000$ lebih kecil dari 0,05 pada sekolah level rendah, yang berarti bahwa peningkatan kemampuan pemecahan masalah matematis siswa berpengetahuan awal rendah yang menggunakan strategi multi representasi lebih baik daripada peningkatan pemecahan masalah matematis siswa yang menggunakan strategi biasa. Hal ini didukung oleh pembelajaran dengan strategi multi representasi yang dapat membangun kepercayaan dirinya melalui bentuk representasi yang dipilihnya, tidak merasa rendah diri, dan takut. Serta bebas memilih bentuk representasi yang diinginkannya serta cocok untuk menyajikan atau menyelesaikan soal matematika yang ia hadapi.

Tidak terjadi interaksi antara siswa yang berpengetahuan awal tinggi dengan faktor pembelajaran. Dengan kata lain bahwa peningkatan pemecahan masalah siswa yang berpengetahuan awal tinggi yang memperoleh strategi multi representasi secara signifikan tidak tampak pengaruh faktor pembelajaran. Sebenarnya ada interaksi tetapi tidak berarti, tampak sejajar, sebab siswa yang berkemampuan awal tinggi kemampuan pemecahan masalahnya juga meningkat, ini menunjukkan bahwa siswa yang berkemampuan awal tinggi lebih mudah beradaptasi dengan beragam strategi, metode, dan pendekatan pembelajaran. Oleh karena itu, butuh waktu yang lebih lama untuk dapat melihat keberhasilan suatu strategi pembelajaran pada kelompok siswa dengan pengetahuan awal tinggi.

Namun demikian peningkatan kemampuan pemecahan masalah siswa berpengetahuan awal tinggi yang memperoleh strategi multi representasi tampak lebih baik dilihat berdasarkan deviasi gain, sebab memiliki gain yang relatif kecil dibanding deviasi gain strategi biasa. Artinya peningkatan kemampuan pemecahan masalah matematis siswa yang memperoleh strategi multi representasi homogen dibandingkan dengan yang memperoleh startegi biasa. Hal ini berarti bahwa siswa yang berkemampuan awal tinggi yang memperoleh pembelajaran dengan strategi multi representasi peningkatan memiliki kemampuan pemecahan masalah matematis yang lebih baik dibandingkan dengan strategi biasa.

\section{Kesimpulan}


Pada akhirnya saya dapat menyimpulkan hasil penelitian tentang strategi multi representasi dengan kemampuan pemecahan masalah yakni: Pertama, siswa yang berkemampuan awal tinggi dalam menyelesaikan soal matematika yang dengan benar, cenderung memilih bentuk representasi aljabar, dan lebih terampil dalam menggunakan berbagai bentuk representasi; Selanjutnya bahwa siswa yang berpengetahuan awal sedang lebih memilih bentuk representasi tabel dan siswa berpengetahuan awal rendah lebih memilih bentuk representasi skema; Kedua, terdapat perbedaan yang signifikan pada peningkatan kemampuan pemecahan masalah matematis siswa yang menggunakan strategi multi representasi dibandingkan dengan peningkatan pemecahan masalah matematis siswa yang menggunakan strategi biasa, baik pada sekolah level sedang dan sekolah level rendah; Ketiga, tidak terjadi interaksi antara siswa yang berpengetahuan awal tinggi dengan faktor pembelajaran yang menggunakan strategi multi representasi dan konvensional. Sebab pada siswa yang berkemampuan awal tinggi yang menggunakan strategi biasa, kemampuan pemecahan masalahnya juga meningkat, ini menunjukkan bahwa siswa yang berkemampuan awal tinggi lebih mudah beradaptasi dengan beragam strategi, metode, dan pendekatan pembelajaran; Interaksi antara siswa yang berpengetahuan awal sedang dan rendah lebih efektif terhadap faktor pembelajaran, karena siswa dapat membangun kepercayaan dirinya melalui bentuk representasi yang dipilihnya. Siswa bebas memilih bentuk representasi yang diinginkannya serta cocok untuk menyajikan atau menyelesaikan soal matematika yang ia hadapi.

\section{Implikasi}

Penelitian ini telah menunjukkan bahwa strategi multi representasi penting diberikan dalam rangka meningkatkan kemampuan pemecahan masalah matematis siswa Sekolah Menengah Pertama (SMP), untuk semua level. Dalam menyampaikan ide-ide matematika perlu menggunakan bentuk-bentuk representasi yang berbeda untuk pencapaian kemampuan pada tingkat tertentu, sehingga mempermudah pemahaman kemampuan pemecahan masalah matematis masing-masing siswa.

Hasil penelitian ini memberikan beberapa implikasi, antara lain: (1) implikasi terhadap perencanaan dan pengembang kurikulum 2013 Sekolah Menengah Pertama (SMP), (2) implikasi terhadap pengembang dan penyusun silabus SMP, dan (4) implikasi terhadap usaha sadar sebagai peran penting institusi pendidikan dalam turut merumaskan, mengembangkan serta mewujudkan masyarakat belajar, melalui sekolah sebagai pilar utama. 
1. Pengembang kurikulum yang sedang berlaku pada Sekolah Menengah Pertama (SMP), hendaknya strategi multi representasi dipertimbang dan dirancang dan disesuaikan dengan keberagaman kondisi, latar belakang siswa, karena dapat menyentuh dan mempermudah kebutuhan setiap siswa.

2. Penyusunan dan pengembang silabus SMP, mengacu pada kurikulum yang berlaku dan penyusunan perangkat-perangkat komponennya, dipertimbangkan untuk melibatkan ahli yang relevan dengan strategi multi representasi, untuk memberikan pengalaman mengajar, cara mengajar demi keberhasilan suatu proses belajar mengajar.

3. Implikasi terhadap usaha sadar sebagai peran penting institusi pendidikan dalam mengembangkan serta mewujudkan masyarakat belajar, melalui sekolah sebagai pilar utama. Diharapkan dapat mengembangkan gagasan strategi mullti representasi secara terprogram dan sistematis, demi tercapai keberhasilan tujuan institusi.

\section{Saran}

Berdasarkan hasil penelitian yang telah disimpulkan dan dalam meningkatkan kemampuan pemecahan masalah matematis siswa Sekolah Menengah Pertama (SMP), dikemukakan beberapa saran sebagai berikut.

1. Kepada para guru, dalam kegiatan proses belajar mengajar di sekolah, disarankan untuk menggunakan pembelajaran dengan strategi multi representasi untuk mempermudah pemahaman kemampuan matematika siswa. Dengan pertimbangan bahwa siswa dapat membangun kepercayaan dirinya melalui bentuk representasi yang dipilihnya, tidak merasa rendah diri, dan takut. Siswa bebas memilih bentuk representasi yang diinginkannya serta cocok untuk menyajikan atau menyelesaikan soal metematika yang ia hadapi.

2. Kepada para pemegang kebijakan dalam pendidikan disarankan untuk menyediakan perangkat guna mendukung kebutuhan pelaksanaan pembelajaran strategi multi representasi

3. Dengan adanya beberapa keterbatasan dalam penelitian ini, kepada peneliti lain diharapkan untuk mengadakan penelitian sejenis yang lebih lanjut dengan mengambil wilayah penelitian yang lebih luas, dengan sampel yang lebih banyak, juga melakukan penelitian pada tingkat yang lebih tinggi pada siswa SMA atau Universitas, sehingga dapat ditemukan hasil yang lebih optimal dan bisa digeneralisasikan pada wilayah yang lebih luas. 


\section{Daftar Pustaka}

Hudiono, B. (2005). Peran Pembelajaran Diskursus Multi Representasi terhadap Pengembangan Kemampuan Matematik dan Daya Representasi pada Siswa SLTP. Bandung: Disertasi pada SPs UPI. Tidak diterbitkan.

Hutagaol, K. (2008). Uji Coba Terbatas Kemampuan Representasi Siswa pada Sekolah Menengah Pertama. Tidak diterbitkan.

Kalathil, R. R., \& Sherin M. G. (2000). Role of Students' Representations in the Mathematics Classroom. Radha R. Kalathil, Miriam Gamoran Sherin. School of Education and Social Policy, www . umich. edu/ icls/ proceedings/pdf/Kalathil.

Kieran, C. (2006). Research on the learning and teaching of algebra. In A. Gutiérrez \& P. Boero (Eds.), Handbook of research on the psychology of mathematics education (pp. 11-50). Rotterdam: Sense.

Kramarski, B. (2000). The Effects of Instructional Methods on the Ability to Communicate mathematical Reasoning. In T. Nakahara \& M. Koyama.

Mudzakkir, H. S. (2006). Strategi Pembelajaran Think-Talk-Write untuk Meningkatkan Kemampuan Representasi Matematik Beragam Siswa Sekolah Menengah Pertama. Bandung: Tesis pada SPs UPI. Tidak diterbitkan.

Neria, D. and Amit, M (2004). Students Preference of Non Algebraic Representations in Mathematical Comunication. Proceding of the International Group for the Psychology of Mathematics Education, Vol. 3 pp 409-416.

Polya. (1985). How to Solve It. A New Aspect of Mathematical Method. Second Edition. New Jersey: Princeton University Press.

Ruseffendi, E. T. (1991). Pengantar kepada Mengembangkan Kompetensi Guru Matematika untuk Meningkatkan CBSA. Bandung: Tarsito.

Sabandar, J. (2006). Model dalam Pembelajaran Matematika Realistik. Jurnal Matematika, Ilmu Pengetahuan Alam, dan Pengajarannya. Mipa Tahun 35, No 2, Hlm. 121-261, ISSN 0854-8269. Malang.

Sudjana. (1996). Metode Statistik. Bandung: Tarsito

Suherman, E., Turmudi, Suryadi, D., Herman, T., Suhendra, Prabawanto, S., Nurjanah, dan Rohayati, A. (2001). Strategi pembelajaran Matematika Kontemporer. Bandung: JICA UPI.

Sumarmo, U. (1987). Kemampuan Pemahaman dan Penalaran Matematika dengan Kemampuan Penalaran Logik Siswa dan Beberapa Unsur Proses Belajar Mengajar. Bandung: Disertasi pada SPs UPI. Tidak diterbitkan.

Sumarmo, U. (2005). Peranan kemampuan Logik dan Kegiatan Belajar terhadap Kemampuan Pemecahan Masalah pada Siswa SMA di Kodya Bandung. Laporan Penelitian FPMIPA IKIP Bandung.

Sutrisno, A.B.J. 92002). Kemampuan pemecahan Masalah Siswa dalam Geometri melalui Model Pembelajaran Investigasi Kelompok. Bandung: Tesis pada SPs UPI. Tidak diterbitkan

Wahyudin (1999). Kemampuan Guru Matematika, Calon Guru Matematika, dan Siswa dalam Mata Pelajaran Matematika. Bandung: Disertasi pada SPs UPI. Tidak diterbitkan. 